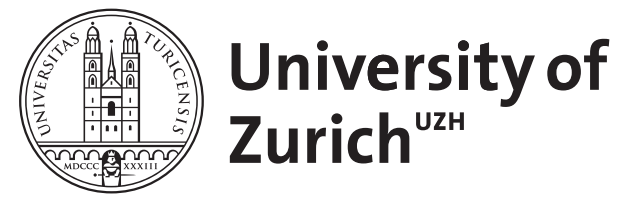

Zurich Open Repository and Archive

University of Zurich

University Library

Strickhofstrasse 39

CH-8057 Zurich

www.zora.uzh.ch

Year: 2008

\title{
Out of joint? - Hong Kong's international status from the Sino-British joint declaration to the present
}

Langer, Lorenz

Posted at the Zurich Open Repository and Archive, University of Zurich ZORA URL: https://doi.org/10.5167/uzh-93994

Journal Article

Originally published at:

Langer, Lorenz (2008). Out of joint? - Hong Kong's international status from the Sino-British joint declaration to the present. Archiv des Völkerrechts, 46:309-344. 


\title{
Out of Joint? - Hong Kong's International Status from the Sino-British Joint Declaration to the Present
}

\author{
LORENZ LANGER*
}

\section{Introduction}

During the failed talks on Kosovo held in Vienna in November 2007, Boris Tadič, President of Serbia, surprised other participants by suggesting to adopt the Hong Kong formula "one country - two systems" to Kosovo. ${ }^{1}$ The immediate rejection of this suggestion (it was considered "irrelevant" by the Kosovar negotiators) might to some extent have been due to the fact that neither the participants nor the media knew what to do with it, or what it actually referred to. Hong Kong seemed far away not only geographically: Since its return to China in 1997, the former colony has attracted little attention, and its status does not seem to warrant further discussion - it is now part of China. But what does "one country - two systems" actually stand for? Was this formula only meant to gloss over the absorption of Hong Kong into China? Or does it entail a different status for the territory, a status that might also offer a solution for other, similar situations? On February 17, 2008, the Kosovar Parliament declared the independence of Kosovo and the suggestion of President Tadič is unlikely ever to be seriously considered. Still, the sudden reappearance of Hong Kong in such a different context might suggest that its relevance on the international level has not expired with the hand-over ceremony.

In December 1984, the United Kingdom and the People's Republic of China (PRC) signed a "Joint Declaration on the Question of Hong Kong", in which Britain agreed to restore the territory to China in 1997. In return, the People's Republic promised to establish a Hong Kong Special Administrative Region (HKSAR), which, following the principle of "one country - two systems", would "enjoy a high degree of autonomy" and be

* M. Phil. (Cambridge), lic. phil. (Zurich), lic. iur. (St. Gallen), Attorney-at-law; Research Fellow, Institute of Public International Law, University of Zurich. I would like to thank Teresa Kam, Prof. Daniel Thürer and Prof. Kay Hailbronner for their support.

1 Veronika Oleksyn, Serbs suggest Hong Kong model for Kosovo, USA Today, Nov. 5, 2007. 
vested "with executive, legislative and independent judicial power". 2 The Region's government and legislature would be composed of local inhabitants, with a Chief Executive appointed by the Central People's Government (CPG) "on the basis of the results of elections or consultations to be held locally". The legislature would "be constituted by elections". 3 Rights and freedoms, including those of the person, speech and press, of assembly and association, of travel, movement and correspondence, of strike and choice of occupation, of academic research and of religious belief, were to be ensured by law. ${ }^{4}$ And, using the name of "Hong Kong, China", the Hong Kong Special Administrative Region would be allowed to maintain and develop economic and cultural relations on its own and to conclude agreements with States, regions and relevant international organisations. ${ }^{5}$ Thus, the Declaration addressed two separate aspects of Hong Kong's future status: Firstly, its constitutional position as a sub-entity (for lack of a more precise denomination) within and towards the People's Republic; secondly, the establishment of a qualified legal personality for the territory under international law. The policies stated in the Declaration would be stipulated in a Basic Law by the National People's Congress (NPC) of the People's Republic and remain unchanged for fifty years. ${ }^{6}$

The return of Hong Kong to China took duly place on $1^{\text {st }}$ July $1997,{ }^{7}$ and the territory just celebrated the tenth anniversary of this "red letter day". 8 According to Hong Kong's Chief Executive Donald Tsang, the celebrations acknowledged the success of "one country - two systems", a concept which, in the decade past, had "grown from an untested idea into a living, breathing reality". He stated that now, "Hong Kong people were running Hong Kong with the high degree of autonomy that had been promised", with the CPG "unwavering in its commitment to make this happen". 9

But have the principles of the Joint Declaration indeed been adhered to since sovereignty passed to China? Has Hong Kong been granted the "high degree of autonomy" it was promised in 1984, and have the provisions on

2 Joint Declaration on the Question of Hong Kong art. 3(2) and 3(3), China-U.K., Dec. 19, 1984, 1399 U.N.T.S. 61.

3 Joint Declaration art. 3(4).

4 Joint Declaration art. 3(5).

5 Joint Declaration art. 3(10).

6 Joint Declaration art. 3(12); The Basic Law of the HKSAR (Zhongua Renmin Gongheguo Xianggang Tebie Ji Ben Fa [hereinafter Basic Law]) was adopted on April 4, 1990.

7 On the handover and the preceding negotiations see Steve Tsang, A Modern History of Hong Kong (2004), 211-267; Sze-Yueng Chung, Hong Kong's Journey to Reunification (2001), 25-136; Chris Patten, East and West (1998), 38-83; Peter Wesley-Smith, Unequal Treaty, 1898-1997 (2nd ed. 1998).

8 Cf. Jang Zemin, Speech at Ceremony for Establishment of HKSAR 1 July 1997, http:// www.fmprc.gov.cn/eng/ljzg/3566/t25959.htm (last visited Apr. 9, 2008).

${ }^{9}$ Donald Tsang, HKSAR 10th Anniversary, http://www.gov.hk/en/theme/10/index. htm (last visited Apr. 9, 2008). 
its international legal capacity and its constitutional framework been implemented? On the one hand, Hong Kong seems to play an independent and considerable international role: In December 2005, the Special Administrative Region hosted the Sixth Ministerial Meeting of the World Trade Organisation (WTO), in which it participated on equal footing with the People's Republic of China. Also, the Chief Executive of Hong Kong features regularly on the "class photos" that conclude the Annual Leaders' Meetings of the Asia-Pacific Economic Co-operation (APEC), most recently sporting a stockman's coat in Sydney. ${ }^{10}$ There are numerous other tokens generally associated with sovereignty: Hong Kong has its own currency; it operates a separate postal system with its own stamps; it has its own police forces; Cathay Pacific is its "national" air carrier. ${ }^{11}$ Its international port is open to any ship. ${ }^{12}$ Indeed, a visitor to Hong Kong has every reason to assume he has entered a separate country: If he liked to spend a day in Guangzhou, he would have to apply (and pay) for a visa to enter the mainland. If, conversely, he travels to Hong Kong from mainland China and is, therefore, not crossing an international border, he will nevertheless have to fill out a visitor's form and pass through Immigration. Once in the HKSAR, he would notice more fundamental differences: Contrary to China, the Hong Kong legal system is based on the common law, and in September 2004, the territory selected its legislative body in more or less direct elections - something quite unthinkable in the "people's democratic dictatorship" 13 of the PRC.

Yet at the same time, this seemingly unlimited autonomy is significantly restricted in some regards. While the Chief Executive may be taking pictures with other leaders during the annual APEC meetings, he is nevertheless required to welcome the Chinese president at the airport, and see him off at the end of each summit. And in Hong Kong, quite apart from stationing the People's Liberation Army in the former British garrison, the Central People's Government has not hesitated to intervene in the constitutional and political set-up of the territory. ${ }^{14}$ While the hand-over of 1997 had been widely covered in western media, these developments have taken place largely unnoticed: The focus has since shifted from the former colony to the mainland, with the brief - and unwelcome - exception of the SARS epidemic in Hong Kong in 2003. Similarly, the peculiarities of Hong Kong

10 The 2007 Apec Leaders' Meeting took place from September 5 to 9 in Sydney.

11 On the relevance of such "attributes of sovereignty" cf. the League of Nations' rejection of Liechtenstein's bid for membership: League of Nations, The Records of the First Assembly, Plenary Meetings, Annex C, 667, 1920.

12 Except for warships, which may access the harbour only with permission of the Central People’s Government (Joint Declaration Annex 1(8)); cf. infra note 95.

13 Constitution of the People's Republic of China, adopted 4 December 1982, art. 1.

14 For an account of recent events, see Lorenz Langer, The Elusive Aim of Universal Suffrage: Constitutional Developments in Hong Kong, Int'l J. Const. L. 5 (2007), 419, 441-449. 
from an international legal perspective received attention mostly in the years preceding the handover. ${ }^{15}$ While several aspects of its constitutional framework continue being discussed on a detailed level, ${ }^{16}$ the legal nature of Hong Kong's establishment under international law has received little attention, ${ }^{17}$ and, in particular, has not been set against recent developments both in the Special Administrative Region and in China.

Consequently, and as far as the two aspects can be considered separately, this paper focuses on Hong Kong's status under international law, rather than on its constitutional autonomy within China. It tries to establish what international legal personality the relevant provisions of the Joint Declaration might entail for Hong Kong, ${ }^{18}$ and whether they have been adhered to. The answer is important on several grounds: Firstly, it does matter whether an emerging world power feels itself bound by international instruments such as the Declaration, even if it were in a position to ignore them. China has long advocated the invalidity of international treaties it considered "unequal"19; adherence to the Joint Declaration, which is a descendant of sorts of the unequal treaties of the imperial age, would confirm a fundamental change in this regard. Secondly, Hong Kong might also be illustrative for another purpose: The traditional categories of international legal personalities, with States as the predominant actors, are becoming increasingly inapt in a world where many issues are decided either on a supranational or, conversely, on a sub-national and regional level. Many States find it difficult to adopt the right framework for such "regionalisation", or for accommodating demands for federal structures or other centrifugal

15 Roda Mushkat, The Transition from British to Chinese Rule in Hong Kong: A Discussion of Salient International Legal Issues, Denver J. Int'l L. and Policy 14 (1986), 171-206; Roda Mushkat, Hong Kong as an International Legal Person, Emory Int'l L. Rev. 6 (1992), 105-170; Martin. P. Scheuer, Die Rechtslage von Hongkong und Macau nach den "Gemeinsamen Erklärungen” vom 19. Dezember 1984 und 13. April 1987 (Europäische Hochschulschriften II 133, 1993); Roda Mushkat, One Country, Two International Legal Personalities (1997).

16 Yongping Ge, Verfassungsrechtliche Grundlagen von Hongkong, Verfassung und Recht in Übersee 35 (2002), 355-372; Johannes Chan et al. (eds.), Hong Kong's Constitutional Debate (2000); Johannes Chan E Lison Harris (eds.), Hong Kong's Constitutional Debates (2005). There is, however, a tendency of both legal scholars and the judiciary to focus on the Basic Law as the sole basis for Hong Kong's autonomy, and to downplay the importance of the Joint Declaration, cf. Chief Judge Chan in HKSAR vs. Ma Wai Kwan David, [1997] 2 HKC 772, at [24], and Yash Ghai, Litigating the Basic Law, in Johannes Chan et al. (eds.), Hong Kong's Constitutional Debate (2000), 6.

17 With the exception of the contribution of Yongping Ge on Hong Kong's capacity to conclude treaties: Völkerrechtssubjektivität und Vertragsabschlußkompetenz von Hongkong, AVR 41 (2003), 220-243.

${ }_{18}$ By "international legal personality", I refer to the (objective) capacity of Hong Kong to act in a manner that is generally reserved for States, cf. James Crawford, The Creation of States in International Law (2nd ed. 2006), 29-30.

19 On unequal treaties see Lucius Caflish, Unequal Treaties, German Y.B. Int'l. L. 35 (1992), 52-80. 
forces. China has consistently upheld State sovereignty as its (almost) sole guiding principle in international relations. ${ }^{20}$ Perhaps to its own surprise, the PRC has now established Special Administrative Regions that supposedly allow not only for separate administration, but even for some independent action on the international level. Thus, Hong Kong might offer China an opportunity to take a more pragmatic view on international relations. In addition, China's attitude towards Hong Kong is also indicative of how it would treat Taiwan were it ever to rejoin the mainland. And perhaps, (positive) Chinese experience with autonomy regimes might even help to find a solution to other conflicts over demands for limited selfgovernment, most notably in Tibet.

\section{Hong Kong's Status in International Law}

The Joint Declaration states that, upon resuming the exercise of sovereignty, the PRC would establish a Hong Kong Special Administrative Region in accordance with Article 31 of the Chinese Constitution. ${ }^{21}$ In establishing this region, China would "take account of the history of Hong Kong and its realities." 22 The importance of history in determining the territory's status is mirrored in the preamble of the Joint Declaration, where Hong Kong is referred to as "question left over from the past". ${ }^{23}$ Therefore, Hong Kong's colonial past should offer some guidance when trying to establish the HKSAR's international status.

20 The principle of sovereign equality has been a cornerstone of Chinese attitudes to international law for the past decades. Respect for its internal and external sovereignty is almost an obsession with the People's Republic. This development is not without irony. The notion of sovereignty was central to the (European) public international law of the $19^{\text {th }}$ century, while it was unfamiliar to Imperial China, which had a far more "permeable" view of relations between different people (rather than nation-States). This unfamiliarity accounted for much of the Chinese difficulties with European concepts of international law in the $19^{\text {th }}$ century. The experience of western domination (and condescension) has led the Chinese to insist on the principle of sovereignty, which, by now, has lost its paramount importance in western international law.

${ }^{21}$ Joint Declaration Art.3(1). Chinese Constitution art. 31 (P.R.C) provides for the establishment of "special administrative regions when necessary", with "the systems to be instituted in special administrative regions ... prescribed by law enacted by the National People's Congress in the light of the specific conditions".

22 Joint Declaration art. 3(1).

23 Joint Declaration, preamble. 


\section{Hong Kong Under British Rule: \\ A Nascent International Personality}

Most parts of the Empire the British had built after the loss of their NorthAmerican colonies were granted some form of self-administration before eventually achieving independence and international legal personality. The settled colonies were allowed to establish their own legislatures, ${ }^{24}$ and the Colonial Laws Validity Act 1865 stated that no law enacted by such legislature should be void unless repugnant to an Act of Parliament. ${ }^{25}$ The Imperial Conferences of 1923 and 1926 acknowledged the autonomy of the older dominions - notably Canada, Australia, New Zealand and South Africa-, which, under the Statute of Westminster 1931, were granted plenary legislative competence and immunity from English parliamentary jurisdiction. ${ }^{26}$ This, however, did not include treaty-making powers. English constitutional law attributes such powers exclusively to the Crown and, the Crown being one and indivisible, they could not be devolved to the dominions. Regardless of this restriction, the dominions started concluding agreements of an international nature well before the Statute of Westminster. ${ }^{27}$ Also, application of commercial treaties concluded by the Imperial Government to the dominions increasingly depended on the latter's voluntary adherence, and by the early $20^{\text {th }}$ century the dominions were granted the power of separate denunciation. ${ }^{28}$ When this was complemented with the capacity to conclude agreements of a political nature in 1926, the dominions had in fact acquired "international treaty-making faculties of a sort", ${ }^{29}$ their devolution constituting an act of State succession. Similar developments took place, with some delay, in other British possessions, most of which acquired qualified international status before achieving full independence.

24 "A settled colony is one in which British subjects were the first settlers with a developed system of laws”, D. P. O'Connell, State Succession in Municipal Law and International Law (1967), vol. II, 36-37.

${ }_{25}$ An Act to remove Doubts as to the Validity of Colonial Laws (Colonial Laws Validity Act), 1865, $28 \& 29$ Vict., c. 63, $\$ 3$ (U.K.).

26 Statute of Westminster, 1931, 22 Geo. 5, c. 4, $\$ 4$ (U.K.).

27 As early as 1874, Australian colonies negotiated international postal agreements; Canada concluded several tariff agreements with other nations in the 1880 s (D.P. O'Connell, supra note 24 , at 39-40).

28 D.P. O'Connell, supra note 24 , at 41.

29 D.P. O'Connell, supra note 24 , at 44 . The contradiction to the unity and indivisibility of the Crown was solved by considering such treaties as inter-governmental, as opposed to Head-of-State treaties concluded by the monarch and applying to the entire empire. 


\section{a) Development of Hong Kong's Treaty-making Powers Under British Rule}

Contrary to most other colonies, there was no development towards a local representative legislature in Hong Kong; changes to the essentially gubernatorial regime were only introduced after the colony's return to China had been agreed upon. ${ }^{30}$ Yet in other aspects, the territory was clearly following the pattern established by the older dominions in the late $19^{\text {th }}$ century, and by other British possession in the $20^{\text {th }}$ century. The first international instrument concluded by Hong Kong - with the consent of the United Kingdom - was a commercial agreement with Burma in 1954. ${ }^{31}$ When Lord McNair considered the agreement in 1961, he stated that it was "believed unusual". ${ }^{32}$ But by 1967, this approach had become normal practice for Hong Kong, and similar textile agreements had been concluded with West Germany and the United States. ${ }^{33}$ By that time, Hong Kong was also represented by a delegation of its own in negotiations with EFTA States. ${ }^{34}$ Hong Kong's independent negotiating powers within EFTA were extended to the EEC upon Britain's accession in 1973, even though the effectiveness of any measure by the colony to safeguard its interests still depended heavily on the support of the United Kingdom, which sometimes pursued conflicting aims. ${ }^{35}$ Additionally, the colony had been allowed to set its own exchange rate for the Hong Kong Dollar in 1967, and from 1974 was able to invest its reserves in any currency. ${ }^{36}$ The Hong Kong govern-

30 The constitutional system of Hong Kong under British rule was determined by a series of Letter Patents (of 1843, 1917, 1985, 1991 and 1993 respectively). They provided for a largely autonomous Governor with full executive and considerable legislative powers, supported by an (advisory) Executive Council (ExCo) and a Legislative Council (LegCo), the approval of which was required to enact laws. Up to 1985, all LegCo members were appointed by the Governor; in 1985, 24 out of 60 Counsellors were elected by a limited electorate. Presently, 30 members are selected in direct elections, whereas the remaining 30 seats are filled through "functional constituencies". For a detailed account of the colonial system see Peter Wesley-Smith, Constitutional and Administrative Law in Hong Kong, 2nd ed. 1993. The more recent constitutional and political developments are traced in Johannes Chan E Lison Harris, supra note 16.

31 Agreement between the Government of Hong Kong acting with the consent of the Government of Great Britain and Northern Ireland, and the Government of the Union of Burma for the Supply of Cotton Textiles of 6 February 1954 (Cmnd. 738, 1954).

32 Arnold D. McNair, The Law of Treaties (2nd ed. 1961), 118 n. 3.

33 A.R. Dicks, The Law and Practice of Hong Kong and Foreign Investment, in V. Shepherd (ed.), Roundtable Conference on International Law Problems in Asia, 2-6 January 1967 (1969), 156. In the 1970s, the clause stating the United Kingdom's consent to the conclusion of the international instrument in question was more and more frequently omitted from treaties and agreements entered into by Hong Kong: Roda Musbkat, The Transition from British to Chinese Rule in Hong Kong: A Discussion of Salient International Legal Issues, Denver J Intl L and Policy 14 (1986), 171, 172-173.

34 Dicks, supra note 33, at 155.

35 Particularly when it came to textile quotas: Norman Miners, The Government and Politics of Hong Kong (5th ed. 1998), 220.

36 Miners, supra note 35, at 215 . In early 1996, the colony's foreign reserves amounted to 
ment built up a considerable network of overseas offices, ${ }^{37}$ which were complemented by seven Investment Promotion Units and over fifty offices of the Trade Development Council.

Thus, even though English constitutional law would suggest that the colony was, up to the hand-over, completely subordinate to the Crown, Hong Kong enjoyed a considerable degree of autonomy not only in internal, but also in international matters. It has even been said that the discussions between the metropolitan and Hong Kong were sometimes much more like diplomatic negotiations between two sovereigns, and not like the subservient relations that the relevant constitutional documents would suggest. ${ }^{38}$

\section{b) Colonial Hong Kong's Participation in International Organisations}

The colony also maintained manifold relations with international organisations. Again, such relations would seem restricted to States and incompatible with the sole responsibility of the United Kingdom for international affairs. In some international organisations, Hong Kong did indeed participate as a part of the British delegation and was consulted only in matters related to the territory. ${ }^{39}$ This approach applied with regard to the funds, programmes and offices of the United Nations which, according to Article 4(1) of the United Nations Charter, are open only to sovereign States. The same restriction applies to most Specialised Agencies associated with the United Nations, in which Hong Kong was also represented by the United Kingdom. ${ }^{40}$ The option of associate membership for dependent territories offered by several Specialised Agencies was exercised with

US \$ 57 billion, the world's seventh largest (Yash Ghai, Hong Kong's New Constitutional Order (2nd ed. 1999), 457). Currently, they stand at US \$ 160.3 billion (excluding gold: $\mathbf{w w w}$. economist.com/indicators, Foreign Reserves as of Apr. 10, 2008; last visited on Apr. 11, 2008).

37 In 1997, Hong Kong maintained ten Economic and Trade Offices in Europe, North America and Asia (Information Services Department, Hong Kong - A New Era (Hong Kong Yearbooks, 1998), Appendix 5(II), available at http://www.yearbook.gov.hk/1997/ eindex.htm.

${ }^{38}$ Miners, supra note 35, at 214. The executive powers of the Crown over Hong Kong were significantly restricted by long-standing conventions, as was the legislative power of Parliament.

39 Gilbert H. Gornig, Hongkong: Von der britischen Kronkolonie zur chinesischen Sonderverwaltungszone (Bibliothek Wissenschaft und Politik 55, 1998), 124.

40 See e.g. WIPO Convention art. 5 [1988] (the dates in square brackets indicate, where available, the first year Hong Kong participated in the British delegation); IMF Articles of Agreement art. 2 (Membership of the IBRD, IDA, and IFC are dependent on membership of the IMF) [n/a]; IAEA Statute art. 4 [early 1960s]; ICAO (Convention on International Civil Aviation) art. 1 and 48(b)) [late 1940s]; UPU (1874 Treaty of Berne) [1877]. For Hong Kong's participation in international organisations, see http://www.info.gov.hk/cab/topical/ (follow “external affairs” hyperlink) (last visited Apr. 9, 2008). 
regard to the International Labour Organisation, ${ }^{41}$ but not for other Agencies. $^{42}$

Not surprisingly, Hong Kong's participation in international relations has been most intensive, and most independent, in the field of economic affairs. Hong Kong has been a full member of the Asian Development Bank since $1969 ;{ }^{43}$ furthermore, it enjoys full membership of the International Textiles and Clothing Bureau since 1985, of the World Customs Organisation since 1987, and APEC since $1991 .{ }^{44}$ Also, it participates in the Asian Productivity Organisation, ${ }^{45}$ and became a full member of the Bank for International Settlements shortly before the handover of 1997.46 Yet the most important token of Hong Kong's international legal personality under British rule has been its involvement with the General Agreement of Tariffs and Trade (GATT) and, subsequently, the World Trade Organization (WTO).

The United Kingdom signed the GATT in 1947. This signature extended to Hong Kong, as each government accepting the agreement did so in respect of its metropolitan territory and of other territories for which it had international responsibility. ${ }^{47}$ Under the terms of the Agreement, Hong Kong, as a "territory with respect to which separate tariffs or other regulations of commerce are maintained for a substantial part of the trade of such territory with other territories", was designed a separate customs territory. ${ }^{48}$ Consequently, it was to be treated, for the purposes of the territorial application of the Agreement, as though it were a contracting party. ${ }^{49} \mathrm{But}$ the Agreement, already progressive in its treatment of dependent territories, in fact allows for separate custom territories to become contracting

${ }^{41}$ Hong Kong participated in the ILO as non-metropolitan territory based on British membership, cf. ILO Constitution art. 35 .

42 The World Health Organisation (WHO Constitution art. 8), the Food and Agriculture Organisation (FAO Constitution art. 2(11)), the UNESCO (UNESCO Constitution art. 2(3)), and the International Maritime Organisation (IMO Convention art. 8) accept territories not being responsible for the conduct of their international affairs as associate members. However, Britain was not a member of UNESCO between 31 December 1985 and 1 July 1997.

${ }^{43}$ http://www.adb.org/About/members.asp (last visited Apr. 9, 2008). Membership of territories not responsible for their foreign affairs presupposes (associate) membership of UNESCAP, a condition that Hong Kong fulfils since 1947 (see ADB Agreement art. 3).

${ }^{44}$ http://www.info.gov.hk/cab/topical/index4.htm (follow "Intergovernmental Organizations not limited to States" hyperlink) (last visited Apr. 9, 2008).

45 Even though membership to the APO is open to "Governments" only: APO Convention art. 3 and 46(1).

46 For a complete list of the international organisations to which Hong Kong was a member prior to the handover, see Union of International Associations (ed.), Yearbook of International Organisations 1996/1997 (1996), vol. II, 627-636.

47 General Agreement on Tariffs and Trade, Oct. 30, 1947, B.I.S.D. IV/1, 45, 55 U.N.T.S. 194 [hereinafter GATT 1947] art. 26(5)(a).

48 GATT 1947 art. 24(2).

49 GATT 1947 art. 24(1). 
parties in their own right if they possess or acquire full autonomy in the conduct of their external commercial relations. Such a territory would be deemed a contracting party upon sponsorship through a declaration by the responsible contracting party establishing the required autonomy. ${ }^{50}$

In the Joint Declaration, the United Kingdom and China (which was not yet a party to the GATT) had agreed that Hong Kong would be allowed to "participate in relevant international organisations and international trade agreements (including preferential trade arrangements), such as the General Agreement on Tariffs and Trade and arrangements regarding international trade in textiles". ${ }^{51}$ In 1986, both governments declared that Hong Kong should become a contracting party in its own right. ${ }^{52}$ As such, it automatically became a founding member of the World Trade Organisation in 1995. ${ }^{53}$

By their declaration to the GATT Secretariat, both China and the United Kingdom had therefore recognised that Hong Kong possessed "full autonomy in the conduct of its external commercial relations". In other words, Hong Kong enjoyed all rights and duties on the international plane, if only for the purposes of trade and commerce. For these purposes, the colony was clearly considered a subject of international law and enjoyed international legal capacity. Yet it is important to point out that this capacity was not only due, but also limited, to commercial and industrial policies. There would have been many more areas in which the United Kingdom could have given Hong Kong more autonomy to act independently on the international level: Hong Kong might well be known first and foremost as "an international financial centre", ${ }^{44}$ but that does not prevent its people from falling ill, requiring food, or from pursuing cultural and educational ambitions. Consequently, it would have seemed natural to offer them the opportunity to voice these concerns through membership, or associated membership, in the relevant international organisations. However, the United Kingdom decided to limit colonial autonomy to the economic field and, by doing so, set a precedent for the Chinese approach to Hong Kong as well.

Nevertheless, the significant international legal standing of the colony might well have been unique to any territory under British rule, and it was

50 GATT 1947 art. 26(5)(c).

51 Joint Declaration Annex I(6). From 1974 to 1994, Hong Kong was a member of the Multifibre Arrangement (Arrangement Regarding International Trade in Textiles, Feb. 8, 1974, GATT B.I.S.D. (21st supplement) at 4), which was replaced by the WTO Agreement on Textiles and Clothing, LT/UR/A-1A/11 (May 15, 1995).

${ }^{52}$ Hong Kong became a contracting party on 24 April 1986: Gornig, supra note 39, at 123.

53 Marrakesh Agreement Establishing the World Trade Organization art. 11(1) (May 15, 1994) LT/UR/A/2.

54 Joint Declaration art. 3(7). 
probably equal to that of the older dominions before the Statute of Westminster. Yet in contrast to these dominions, and indeed to all other British possession, the economic development stood in stark contrast with the lack of political devolution from the municipal country. In the early 1980 s, by a time when all former British colonies in Africa had long secured independence, Hong Kong was still to take the first steps that would lead to significant political autonomy of the territory. If, indeed, Hong Kong would have appeared to be a nascent international personality from the late 1960s onwards, its proper delivery was delayed beyond the due date, took place in a botched manner and left it impaired from birth on the international plane. The reasons for this outcome are manifold. Hong Kong's position was unique among Britain's colonies insofar as its future was not a matter to be agreed upon between the metropolitan State and the dependent territory alone: With China, there was a major third player involved. ${ }^{55}$ And even though this player decided to stay at the sidelines for a century and half, its presence nevertheless influenced any move on the pitch. Furthermore, while the British credited Hong Kong's inhabitants with great economic skills, they also perceived them as being solely concerned with the accumulation of material wealth. It is difficult to tell whether this cliché was a cause for, or a consequence of, the denial of political participation for locals. ${ }^{56}$ It has, in any case, been gratefully adopted by the new sovereign: In his speech at the handover ceremony, President Jiang Zemin stated that the Hong Kong compatriots would regard it "as their utmost honour to maintain long-term prosperity and stability in Hong Kong”. ${ }^{57}$

\section{Hong Kong's Status under the Joint Declaration}

Jiang Zemin also maintained that from now on, "Hong Kong compatriots [would] truly become the masters here”. He repeated Deng Xiaoping's promise of "Hong Kong people administering Hong Kong" and also reiterated the latter's belief that the Hong Kong Chinese "have the ability to

55 And in contrast to the Falkland Islands and Argentina, a military confrontation with China over Hong Kong was not an option.

56 The latter seems more likely, as David Faure has argued: "I have often found it a strange anomaly that in the politically turbulent twentieth century the argument could have been made, that Chinese people were uninterested in politics. Rather, politics being the exertion of power within the realms of the possible, Hong Kong people, like people in most societies, exerted their power in the realms that have been defined for it" (Colonialism and the Hong Kong Mentality (2003), 2).

${ }^{57}$ Jang Zemin, Speech at Ceremony for Establishment of HKSAR (July 1, 1997), http:// www.fmprc.gov.cn/eng/ljzg/3566/t25959.htm (last visited Apr. 9, 2008). The same approach is followed by the HKSAR government, which aims to "promote social harmony, and enhance economic growth" (Donald Tsang, 2005-06 Policy Address: Strong Governance for the People, para. 4, http://www.policyaddress.gov.hk/05-06/eng/index.htm (last visited Apr. 9, 2008). 
run the affairs of Hong Kong well". ${ }^{58}$ But into what international legal capacity did and do such statements translate? To what extent are Hong Kong's leaders of today truly their own masters, rather than local administrators for the Central Government?

The problem in answering these questions lies in Hong Kong's nature as a two-faced, hybrid entity with its origins rooted in an international treaty and the Chinese Constitution or, by extension, the Basic Law. ${ }^{59}$ Thus, there is an international law aspect to Hong Kong's personality, and an internal or constitutional perspective. But which one is to take pre-eminence? Was it the Joint Declaration or the promulgation of the Basic Law that actually created today's Hong Kong legal status? The Declaration's wording on this point is ambiguous: China stated "that [...] it had decided to resume exercise of sovereignty over Hong Kong with effect from 1 July 1997”, while the United Kingdom declared that it would "restore Hong Kong to the PRC with effect from 1 July 1997". ${ }^{60}$ This formulation tries to accommodate the contradictory positions of the parties: Britain claimed that it had obtained sovereignty over Hong Kong through the Treaty of Nanking in $1843,{ }^{61}$ while the People's Republic insisted that sovereignty had always resided with China. ${ }^{62}$ Consequently, the Chinese had strong misgivings about concluding an international treaty on the future of Hong Kong. It has been suggested that the Joint Declaration is, in fact, not a binding treaty in international law; ${ }^{63}$ however, the Declaration itself as well as its ratification and subsequent registration with the United Nations leave no doubt that it constitutes an "unequivocally binding international agreement". ${ }^{64}$ At least on the international level, it is therefore the Declaration that should be considered the midwife of the HKSAR. And central to the Joint Declaration is the guarantee for Hong Kong of a "high degree of autonomy". 65

58 Jiang Zemin, supra note 57.

59 The relationship between the Constitution and the Basic Law is anything but clear and open to at least three interpretations: (1) the Basic Law is a self-contained regime; (2) the Basic Law is binding under the law of China, but by promulgating the Basic Law, the NPC has limited its powers with regard to changing the SAR's set-up for fifty years; (3) the Basic Law is a Chinese law that might in fact be changed, but under a presumption against implied repeal: James Crawford, Rights in One Country: Hong Kong and China (Hochelaga Lectures 2004), 17-18.

60 Joint Declaration art. 1 and 2.

61 Treaty of Nanking, UK-China, art. 3, Aug. 29, 1842, 93 Consol. T.S. 467.

${ }^{62}$ Harold C. Hinton, China as an Asian Power, in Th. W. Robinson E D. Shambaugh (eds.), Chinese Foreign Policy: Theory and Practice (1994), 354.

${ }^{63}$ Sze-yuen Chung, What has Gone Wrong During the Transition?, in G. Wang E S. Wong (eds.), Hong Kong's Transition (1995), 3. This view was also promoted by the mainland press, contributing to a considerable fall of the Hang Seng stock market index, WesleySmith, supra note 30 , at $57 \mathrm{n} .13$.

64 Margaret Thatcher, The Downing Street Years (1993), 492. Unofficially, this was already accepted by the Chinese leadership in June 1984 on the occasion of a visit of Unofficial LegCo Members: Chung, supra note 63, at 6-7.

65 Joint Declaration art. 3(2). 
There is no generally accepted definition of "autonomy" for the purposes of international law; ${ }^{66}$ therefore, its meaning with regard to Hong Kong has to be derived from the provisions of the Declaration itself and its object and purpose. ${ }^{67}$ Autonomy in the Joint Declaration includes both an institutional and a personal aspect: Executive, legislative and judicative powers are granted to the HKSAR, and its government will be composed of local inhabitants. ${ }^{68}$ The territory is auto-nomous in the sense proper as it carries primary responsibility for legislation. ${ }^{69}$ In addition, Hong Kong autonomy has to be interpreted in the context of the principle of "one country - two systems", the concept underlying the Declaration. When it was first put forward in the early 1980s, this approach was aimed at the re-unification with Taiwan rather than at the return of Hong Kong. ${ }^{70}$ At the time, however, Taiwan was as much a one-party State as the People's Republic, and the "two systems" therefore referred not to political or constitutional, but solely economic differences: Taiwan would be allowed to follow the capitalist path, while China would continue on the socialist road and slowly adapt some capitalist features. ${ }^{71}$ The same would apply with regard to Hong Kong: Only its current social and economic system and, with some qualifications, its legal system would remain unchanged. ${ }^{72}$ Therefore, the autonomy and, by extension, the treaty-making powers granted to Hong Kong are limited to areas where its "system" differs from the mainland; they refer primarily to "economic and cultural relations". ${ }^{73}$ A slightly larger scope is applied in Annex I to the Declaration, which states that using the name "Hong Kong, China", the HKSAR "may on its own maintain and develop relations and conclude and implement agreements with States, regions and relevant international organizations in the appropriate fields, including the economic, trade, financial and monetary, shipping, communications, tourist, cultural and sporting fields". ${ }^{74}$ As indicated by the emphasis added, this enumeration is not exhaustive. Under the same provision, the HKSAR "may participate in international organisations and con-

${ }^{66}$ Roda Mushkat, One Country, Two International Legal Personalities (1997), 16; Scheuer, supra note 15, at 191-194.

67 Vienna Convention on the Law of Treaties art. 31(1), May 23, 1969, 1155 U.N.T.S. 331 [hereinafter Vienna Treaties Convention].

68 Joint Declaration art. 3(3) and 3(4).

69 Joint Declaration Annex I(2).

70 Peng Zhen, Report on the Draft of the Revised Constitution of the PRC, Delivered at the $5^{\text {th }}$ Session of the $5^{\text {th }}$ NPC on November 26, 1982, Fifth Session of the Fifth National People's Congress (1983), 99-101.

71 Deng Xiaoping, An Idea for the Peaceful Reunification of the Chinese Mainland and Taiwan (June 26, 1983), reprinted in Deng Xiaoping, Selected Works (1994), vol. III, 40.

72 Deng Xiaoping, One Country, Two Systems (June 22-23, 1984), reprinted in Deng, supra note 71 , at $68-71$.

73 Joint Declaration art. 3(10).

74 Joint Declaration Annex I(11)(1). 
ferences not limited to States". In cases that do not fall within Hong Kong's external relation competence, and for the purpose of international organisation limited to States, representatives of HKSAR may be allowed to participate as members of the Chinese delegation. ${ }^{75}$

As quoted above, Annex I(11) to the Declaration states that HKSAR may "on its own" maintain and develop certain external relations. However, Annex I (1) requires the Central People’s Government to “authorise the Hong Kong Special Administrative Region to conduct on its own those external affairs specified". The wording of the two provisions seems difficult to reconcile. While Annex I(11) purports to bestow the capacity to maintain such relations without a need for further measures, Annex I (1) suggests that any such competence would derive from additional Chinese authorisation rather than directly from the Declaration. The distinction is significant: Given China's rigid views on State sovereignty, ${ }^{76}$ any international capacity dependent on Chinese authorisation is likely to be more restricted. The difference also affects the nature of any external competence granted by the Basic Law: If the provision of Annex I(11) applies without further authorisation, such competence would derive from the Declaration directly, with the Basic Law merely implementing the relevant provisions on a national level. If additional authorisation according to Annex I (1) is required, the Basic Law, as an expression of such authorisation, would become the main source for the scope of external competence. Furthermore, changing this scope would be a matter of Chinese discretion. ${ }^{77}$

\section{Compliance of the Basic Law with the Joint Declaration}

In Article 13(3), the Basic Law follows the more restrictive approach by stating that "the Central People's Government authorizes the Hong Kong Special Administrative Region to conduct relevant external affairs on its own in accordance with this Law". Besides detaching external competences from the Joint Declaration, this provision also indicates that any such competence exists only in accordance with, and to the extent specified by, the Basic Law. In other words, any residual powers rest with the People's Republic, and not with the HKSAR.

Article 13 of the Basic Law makes a further distinction quite imperceptible to non-Chinese. Its first paragraph states that "the Central People's Government shall be responsible for the foreign affairs relating to the Hong Kong Special Administrative Region”. To the unsuspecting Western eye,

75 Id.

76 Ghai, supra note 36, at 460; Wang Tieya, International Law in China, in Académie de Droit International (ed.), Recueil des Cours 221 II (1990), 288-295.

77 Basic Law art. 158(1) vests the Standing Committee of the NPC with the power of interpreting the Basic Law. 
the foreign affairs referred to in this provision are not significantly different from the external affairs mentioned in Paragraph 3 of the same article, which might be conducted by the HKSAR upon authorisation. However, in Chinese the two terms carry different meanings. ${ }^{78}$ Foreign affairs are "quintessentially matters of State and international diplomacy", while external affairs "appear to be concerned with economic and cultural matters". ${ }^{79}$ The Joint Declaration, which was signed in both English and Chinese, also distinguishes between foreign and external affairs. ${ }^{80}$ In English, however, the two terms do not carry a significantly different meaning. With both texts being equally authentic, and with the ordinary meaning to be given to the terms of a treaty, ${ }^{81}$ it would be difficult to insist on the applicability of the Chinese differentiation. The Basic Law, on the other hand, was first passed in a Chinese version. Subsequently, an official English version was adopted by the NPC. However, the Chinese version prevails in cases of discrepancy between the two texts. ${ }^{82}$

Thus, the autonomy envisaged by the Joint Declaration has been doubly qualified by the Basic Law with regard to international capacity: Firstly, such autonomy does no longer emanate directly from the Declaration, but depends on authorisation by the Central People's Government; and secondly, it applies, at most, to the narrowed field of "external affairs", i.e. economic and cultural matters only. ${ }^{83}$ This is in line with the general Chinese approach to the international legal capacity of Hong Kong. While the Basic Law vests the HKSAR with considerable powers to conduct its external affairs, these powers are regarded in functional rather than absolute terms. They do not extend further than the maintenance of the Hong Kong system - i.e. capitalism - would require. ${ }^{84}$ The mainland has reinforced this narrow view through the interpretations of the Basic Law by the National People's Congress Standing Committee (NPCSC). Such interpretation is provided for in the Basic Law, yet the NPCSC has used it not for construing a legal text, but rather to determine the boundaries for Hong Kong policies. ${ }^{85}$ It has to be stressed, however, that the only relevant

78 In the Chinese text, foreign affairs translates as waijiao shiwu, and external affairs as dui wai shiwn: Ghai, supra note 36, at 461.

79 See id. The distinction made in Article 13 is reinforced in Article 150, which makes it clear that negotiations "at the diplomatic level”, even if directly affecting the Region, may not be conducted by the HKSAR Government.

80 Joint Declaration art. 3(2) and Annex I (1).

81 Cf. Vienna Treaties Convention art. 31(1).

82 HKSAR vs. Ma Wai Kwan David, [1997] 2 H.K.C 772, at para. 14. The Chinese version of the Basic Law was adopted on 4 April 1990, the English text on 28 June 1990.

83 But see Crawford, supra note 59, at 28, who seems to construe "external affairs" in a broader sense, albeit based solely on the English text of the Basic Law.

84 Deng, supra note 72, at 14.

85 Basic Law art. 158. See: Beijing to Interpret Basic Law on Reforms, South China Morning Post (SCMP), Mar 27, 2007. On the thorny issue of interpretation and the role of 
instrument on Hong Kong's status on the international level is the Joint Declaration, which constitutes a binding international agreement: ${ }^{86}$ Conversely, the Basic Law, as internal Chinese law, may not be invoked to justify any failure to adhere to the Declaration. ${ }^{87}$ If the Basic Law were the sole source for Hong Kong's status, this status could be fundamentally altered through interpretation by the NPCSC ${ }^{88}$ or amendment by the NPC. ${ }^{89}$ Clearly, the Declaration does not allow for such changes.

\section{Hong Kong Autonomy under the Basic Law}

\section{a) Treaty-making Powers}

According to Article 13(3) of the Basic Law, the Central Government "authorises the HKSAR to conduct relevant external affairs on its own" and in accordance with the Basic Law (emphasis added). Article 116(2) authorises Hong Kong to "participate in relevant international organisations and international trade agreements.” Article 151, echoing Annex I(11) of the Joint Declaration, provides for the maintenance and development of certain international relations, and for the conclusion and implementation of international agreements. Again, Hong Kong may exercise these powers on its own, i.e. as a party to the respective treaty, and thus incur international liability for its obligations under it. ${ }^{90}$ On the other hand, Article 153(1) excludes Hong Kong from deciding whether any international agreements to which the People's Republic of China is or becomes a party should apply to the territory: Application of such agreements would be decided on by the Central People's Government "after seeking the views of the government of the Region". ${ }^{11}$ The Central Government would also "authorise or assist

the NPCSC, see Langer, supra note 14, at 441-449. Most recently, the NPCSC has ruled out direct elections for either LegCo or the Chief Executive before 2017: Decision of the NPCSC on Issues Relating to the Methods for Selecting the Chief Executive of the HKSAR and for Forming the Legislative Council of the HKSAR in the Year 2012 and on Issues Relating to Universal Suffrage, Dec. 29, 2007, available at http://www.cmab-gpcd.gov.hk/doc/decision. pdf (last visited Apr. 9, 2008).

86 and not only a "declaration of intent", as stated in HKSAR vs. Ma Wai Kwan David, [1997] 2 HKC 772, at para. 24.

87 Cf. Vienna Treaties Convention art. 27. In the Chinese view, however, Hong Kong's status is determined by the Basic Law alone, with not international strings attached (cf. Crawford, supra note 59 , at 7).

88 Basic Law art. 158.

89 Basic Law art. 159.

90 Such treaties are, therefore, not only Chinese treaties applying exclusively to Hong Kong, but Hong Kong treaties: Crawford, supra note 59, at 30. Since the handover, the HKSAR has concluded over 60 bilateral agreements: http://www.legislation.gov.hk/choice. htm\#bf (last visited Apr. 9, 2008).

91 This is somewhat reminiscent of the Dominions' situation, even though it was they who decided on application of treaties, and not the Imperial Government, supra note 28 and accompanying text. 
the government of the Region to make appropriate arrangements for the application to the Region of other relevant international agreements". ${ }^{2}$

In this context, the agreement to reduce trade barriers concluded between China and the HKSAR is of particular interest. The "Mainland and Hong Kong Closer Economic Partnership Agreement" (CEPA) of 30 June 2003 aims to eliminate tariff and non-tariff barriers on the trade "between the two sides", and to facilitate mutual trade and investment. ${ }^{93}$ Even though the CEPA lists adherence to the approach of "one country - two systems" as its first principle (Article 2(1)), and despite referring to two "sides" rather than parties, it constitutes a treaty between two entities that are, at least for the purpose of the agreement, on equal footing. This is underlined by Article 23, which states that the agreement would come into force "on the day of signature by the representatives of the two sides", and by Article 22 providing for the adoption of amendments by both sides. The CEPA also abides by the rules that the WTO and GATT set for bilateral agreements. ${ }^{94}$ As an economic agreement, the CEPA falls within the scope of Articles 151 and 116(2) of the Basic Law. At the same time, it constitutes an agreement between two WTO members, and two separate customs territory. Such bilateral instruments can be concluded between any other, and possibly sovereign, members of the WTO. Given that Taiwan is also a member of the WTO, it could be argued that any similar agreement between Hong Kong and Taiwan would not need central approval - a prospect that would outrage mainland authorities.

Still, such a wide sense is not generally implied in the "appropriate fields" of Article 151 of the Basic Law. For example, the HKSAR may negotiate air service agreements, but only "under specific authorisation from the Central People's Government” (Article 133). This is considerably more restricted than the competence granted by Article 151 to conclude "on its own" agreements in, inter alia, the economic, trade and tourist field.

92 Basic Law art. 153(2). The wording is somewhat unclear, but "other relevant international agreements” presumably refers to agreements exceeding Hong Kong's capacity under article 151 to which China is not a party and which are not yet implemented in or applied to Hong Kong.

${ }_{93}$ Mainland and Hong Kong Closer Economic Partnership Agreement art. 2, PRCHKSAR, Apr. 29, 2003, translated at http://www.tid.gov.hk/english/cepa/files/main_e.pdf (last visited Apr. 9, 2008). For an introduction, see Henry S. Gao, Legal Issues under WTO Rules on the Closer Economic Partnership Arrangement (CEPA) between Mainland China and Hong Kong, Chin. J. Int'l L. 2 (2003), 629. Annual supplements have been signed between the Mainland and Hong Kong governments. The most recent, Supplement IV (referred to as CEPA V), was signed on June 29, 2007 (Supplement IV to the Mainland and Hong Kong Closer Economic Partnership Arrangement, translated at http://www.tid.gov. hk/english/cepa/legaltext/files/sa4_main_e.pdf (last visited Apr. 9, 2008)).

${ }_{94}$ CEPA art. 2(2), 6(1), 8, 12(1) and 18. Cf. GATT art. XXIV. However, the compatibility of CEPA with GATT is not uncontroversial; for discussion, see Jiaxiang Hu, Closer Integration, Controversial Rules: Issues Arising from the CEPA between Mainland China, Hong Kong, and Macao, 18 Pace Int'l L Rev. 18 (2006), 389, 393-400. 
Generally, express central authorisation or assistance is requested whenever a competence might transgress the cultural and economic sphere: Thus, juridical assistance, visa arrangements, establishing consular offices in Hong Kong, the landing of State aircrafts or the harbouring of warships all require central approval..$^{5}$

\section{b) Participation in International Organisations}

The Basic Law is more coherent with the Declaration with regard to participating in international organisations. Repeating the wording of the Declaration, the Basic Law provides for participation in the "relevant organisations in the appropriate fields". ${ }^{96}$ Also, the Basic Law reiterates the Declaration's restriction of independent participation to "international organisations and conferences not limited to States". ${ }^{97}$ Other organisations "in appropriate fields and open only to States and affecting the Region" may be attended by Hong Kong representatives as part of the Chinese delegation only. ${ }^{98}$

Hong Kong's participation in international organisations prior to the handover has already been discussed. ${ }^{99}$ Membership in these organisations and the WTO in particular continues under Chinese sovereignty. Considered the "freest economy" in the world, ${ }^{100}$ the HKSAR is a staunch proponent of free trade and the multi-lateral trading system; its main aims are to sustain the momentum of trade liberalisation, and to strengthen and update the WTO trading system. ${ }^{101}$ Import tariffs had been abolished under British rule; Hong Kong is advocating further tariff reductions under the WTO regime. ${ }^{102}$ Furthermore, Hong Kong is the only party to the WTO's Government Procurement Agreement that applies its provisions unilaterally, to both signatories and non-signatories. ${ }^{103}$

95 Basic Law art. 96, 155, 157, 126, 129. China has repeatedly used control over Hong Kong harbour for political purposes when denying access to ships of the US Navy even when they were seeking refuge from an approaching storm: Ting Shi, What would happen in a real crisis? SCMP, Nov. 30, 2007.

96 Basic Law art. 151 and Joint Declaration Annex I(11).

97 Basic Law art. 152(2) and Joint Declaration Annex I(11).

98 Basic Law Art. 152(1) and Joint Declaration Annex I(11).

99 See supra note 39 and accompanying text.

100 James Gwartney \& Rober Lawson, Economic Freedom of the World, 2007 Annual Report (2007), 97.

101 HKSAR Government, WTO Trade Policy Review Hong Kong, China (Nov. 18, 2002) at para. 5, WT/TPR/G109, available at www.wto.org/english/tratop_e/tpr_e/g109_e. doc (last visited Apr. 9, 2008).

102 http://www.tid.gov.hk/english/trade_relations/tradefora/wto_tariffnegot.html(last visited Apr. 9, 2008).

103 The Agreement only requires parties to open up government contracts to other signatories: Government Procurement Agreement art. 3(1), April 15, 1994 LT/UR/A-4/ PLURI/2. 
Several offices of international organisations have been set up in Hong Kong: The Bank for International Settlements maintains a regional office in the city, as do the International Monetary Fund, the International Bank for Reconstruction and Development, and the International Finance Corporation. ${ }^{104}$ These organisations are all concerned with economic matters; but even though the Joint Declaration empowered the HKSAR to "conclude relevant agreements with ... relevant international organisations", ${ }^{105}$ the respective host agreements were nevertheless concluded by the Central Government, reiterating the narrow interpretation of Hong Kong's international legal capacity even with regard to economic issues. ${ }^{106}$

Just as under British rule, Hong Kong's participation remains restricted to economic organisations, and the option of associated membership in several Specialised Agencies has not been exercised. ${ }^{107}$ Such membership is not, as claimed by the Hong Kong government, 'limited to sovereign States', ${ }^{108}$ as Macau's associated membership of UNESCO illustrates. ${ }^{109}$ Yet so far, Hong Kong representatives have not been allowed to participate in any of these organisations in an independent capacity. This approach is very much in line with British precedent - and is, consequently, open to the same fundamental criticism. Just as the United Kingdom had done for 150 years, the People's Republic seems to see in Hong Kong nothing more than a powerful - and hopefully profitable - economic resource. Inasmuch as it is necessary to maintain the prosperity and stability of this resource, Hong Kong will be granted autonomy, both internal and external, while anything beyond the fields of trade and commerce does not warrant the delegation of powers to the Special Administrative Region. Of course, the inadequacies of this approach have not changed since the days of British rule. The abysmal handling of the SARS epidemic by the Chinese authorities

104 List of Agreements and Arrangements for the Establishing International Organisations in Hong Kong, http://www.legislation.gov.hk/table7ti.htm (last visited Apr. 9, 2008).

105 Joint Declaration art. 3(10).

106 According to the Basic Law, only the establishment of foreign consulates would require central approval (art. 157(1)).

107 With the exception of the ILO, where Hong Kong membership continues based on "analogous application" of the provisions on non-metropolitan territories: Ghai, supra note 36, at 467 n. 6.

108 See supra note 42, and for the government's position http://www.cmab.gov.hk/en/ issues/external1.htm (last visited Apr. 9, 2008). It is telling (and slightly contradictory) that Hong Kong is indeed an associate member to a number of minor organisations supposedly limited to States (Asia-Pacific Telecommunity (APT); Economic and Social Commission for Asia and the Pacific of the United Nations (ESCAP); Heads of National Drug Law Enforcement Agencies, Asia and Pacific (HONLEA, Asia and Pacific); International Maritime Organization (IMO); World Tourism Organisation).

109 Macao joined in 1995, before it became a Special Administrative Region of China, and has retained its membership: http://erc.unesco.org/cp/cp.asp?country=MO\&language =E (last visited Apr. 9, 2008). The UNESCO is not listed by the Constitutional Affairs Bureau for the purpose of Article 152(1) of the Basic Law, nor for Article 152(2), even though China is a member. 
has had long-lasting consequences for Hong Kong, and might, had the virus spread, have had even more devastating effects in the rest of the world. ${ }^{110}$ The reluctance of China to co-operate with the WHO should have made it more than clear that Hong Kong would have benefited significantly if it had had independent capacity to work with the WHO. China's approach to international organisations, however, seems more guided by concerns over status and sovereignty than by an ambition to further the respective organisation's specific goals. ${ }^{111}$

\section{The Nature of Hong Kong's International Personality}

Even if the Joint Declaration - and, to a larger extent, the Basic Law - restrict the capacity of Hong Kong to act on an international level, act it still can and does. Yet into what kind of legal capacity or status do the relevant provisions of the Joint Declaration translate? Is there any precedent for such an entity on the international level, or does Hong Kong offer an entirely new guise and new opportunities for international legal actors?

In the classical conception of public international law, only sovereign States had the capacity to create and enjoy rights and carry duties on the international level: They were, therefore, the only entities qualifying as subjects of international law. ${ }^{112}$ In practice, however, this approach was far from unequivocal, not least because it presupposes agreement on what a State is: The criteria of statehood are open to interpretation and might be applied more or less stringently according to political considerations (as evidenced by recognition or non-recognition of Kosovo). Also, some entities were recognised as quasi-States for the purpose of their legal personality even though their structure significantly differed from States proper. ${ }^{113}$

110 The disease had been ravaging for several weeks in southern China without the HKSAR authorities being informed by the Central Government; a visiting Chinese doctor then brought SARS to Hong Kong (Christine Loh, The politics of SARS: The WHO, Hong Kong and Mainland China, in C. Lob and Civic Exchange (eds.), At the Epicentre: Hong Kong and the SARS outbreak (2004), 139, 151-154.

111 Despite the need for concerted efforts against avian influenza, China persistently opposes WHO membership of Taiwan (WHO rejects call to consider WHO membership, Reuters, May 14, 2007, http://www.reuters.com/article/latestCrisis/idUSL14534020 (last visited Apr. 9, 2008)).

112 Crawford, supra note 18 , at 29.

113 E.g. free cities such as Krakow, constituted at the Congress of Vienna, or the Swiss Cantons prior to the establishment of the Swiss Federation in 1848: Hermann Mosler, Subjects of International Law, in Rudolf Bernhardt (ed.), Encyclopaedia of Public International Law (1999), vol. IV, 716-17. Before the Oslo process, the claim of Palestine to legal personality was also controversial (see James Crawford, The Creation of a State of Palestine: Too Much Too Soon? Eur. J. Intl L. 1 (1990), 307. Now, the Road Map endorsed by the Security Council provides for a two-State solution: S/RES/1515 (19 November 2003). 
Clearly, Hong Kong is not a State, nor did it ever aspire to be one. Still, it is worth pointing out that under the traditional criteria, ${ }^{114}$ Hong Kong would have a reasonably strong case for statehood: Firstly, it has a relatively large body of permanent residents ${ }^{115}$ who form a community that is distinctive from the population of mainland China: Contrary to the overwhelming majority of the PRC's inhabitants, Hong Kong Chinese speak Cantonese rather than Mandarin; the simplified Chinese characters used on the mainland have not been adopted; and, as accepted in the Joint Declaration as well as the Basic Law, there is a distinct "Hong Kong way" with regard to economic, cultural and political traditions. ${ }^{116}$ The People's Republic itself has acknowledged that the Hong Kong Chinese form a distinct body: Deng Xiaoping had stated that after returning to China, "Hong Kong people" would govern and administer the territory. ${ }^{117}$ This presupposes a defined body of population, and such a body is indeed provided for by the Basic Law with the category of "permanent residents", which is not congruent to that of Chinese citizenship, and for which the HKSAR has the power to issue passports and travel documents. ${ }^{118}$ Secondly, Hong Kong is established within clearly delineated territorial boundaries, comprising the New Territories, Kowloon and Hong Kong proper, as well as a number of smaller islands. Within these boundaries, a political community has been effectively established, and territorial jurisdiction is exercised. ${ }^{119}$ Naturally, this jurisdiction is not unlimited: Yet its restriction is of a gradual nature rather than absolute, ${ }^{120}$ and might be considered akin to the limits that international law imposes on States.

However, statehood not only requires population, territory and government: The Montevideo Convention added, as a fourth criterion, the capacity to enter into relations with other States. ${ }^{121}$ In a more recent definition, the Arbitration Commission of the European Conference on Yugoslavia has set a similar criterion by stating that States are "characterised by sovereignty". ${ }^{122}$ For the present purpose of determining the international

114 Georg Jellinek, Allgemeine Staatslehre (3rd ed. 1914), 394-434.

115 By August 2006, Hong Kong had a population of 6.864 million (HKSAR Census and Statistics Department (ed.), 2006 Population By-Census (2007), 6).

116 Joint Declaration art. 3(12); Basic Law art. 5.

117 Deng, supra note 72 , at 16-17.

118 Basic Law art. 24 and 154.

119 Cf. Joint Declaration art. 3(3), and Basic Law art. 19(2).

120 Cf. Basic Law art. 19(3).

121 Montevideo Convention on Rights and Duties of States art. 1 Dec. 26, 1933, 19 L.N.T.S. 165. For a critical discussion, see Crawford, supra note 18, at 61-62, 436-440.

122 The first three opinions of the Commission, which, after its President, is also referred to as the Badinter Commission, are reprinted in Alain Pellet, The Opinions of the Badinter Arbitration Committee, Eur. J. Int'l L. 3 (1992), 178, 182-84. The first opinion states that "the State is commonly defined as a community which consists of a territory and a population subject to an organized political authority; that such a State is characterised by sovereignty" (at 182). 
legal personality of Hong Kong, the central aspect of the principle of sovereignty is independence of any higher authority other than the rules of international law, or international obligations entered into freely. ${ }^{123} \mathrm{Con}-$ versely, the Joint Declaration stated unequivocally that China would exercise sovereignty in Hong Kong. ${ }^{124}$ Even though the territory would enjoy a high degree of autonomy, the People's Republic would be responsible for its foreign and defence affairs. ${ }^{125}$ Other indications of a lack of sovereignty are the "expiry date" on its present way of life ${ }^{126}$ and the determination of its legal status as a Special Administrative Region by the Chinese Constitution. ${ }^{127}$

It is not argued here that Hong Kong should, in fact, be recognised as a State in any sense. No matter how many legal criteria for statehood it meets, Hong Kong is considered part of China not only by the Chinese government, but by Hong Kongers as well. However, the fact that Hong Kong is, in so many ways, akin to a State may help to determine the degree of international personality it could and ought to have.

\section{Precedents Under Municipal and International Law}

Under what guise, then, does Hong Kong participate in international affairs? Other non-State actors have previously been vested with some international capacity, most notably the Soviet republics of Ukraine and Byelorussia, which were founding members of the United Nations even though membership is open only to States proper. ${ }^{128}$ Subdivisions of federal States may also hold international capacity and even be entitled to conduct foreign relations within the scope granted by the respective federal constitution. ${ }^{129}$

123 So already Jean Bodin, who described sovereignty as "la puissance absolue et perpétuelle d'une République" unbound by its own laws (leges) or any other secular authority (Six livres de la République (1578) (Corpus des œuvres de philosophie en langue française, 1986), I, 8. Even though he does not explicitly refer to international law, his concept of binding natural law (ius) serves the same purpose of restricting State discretion in international relations (Steinberger, in Rudolf Bernbardt (ed.), supra note 113, at 505). More recently, it has been argued that "the anachronistic idea of total independence and autonomy of the State" has "no real meaning today": Jonathan Charney, Review of International Decisions in National Courts, Amer. J. Int'l L. 91 (1997), 394, 395, and that consequently, “the word 'sovereignty' should be stricken from our vocabulary" (Lonis Henkin, The Mythology of Sovereignty, Amer. Soc. Int'l L. Newsletter, March-May (1993), 1).

124 Joint Declaration art. 3(1).

125 Joint Declaration art. 3(4).

126 Joint Declaration art. 3(12).

127 Joint Declaration art. 3(1).

128 U. N. Charter art. 4(1), cf. Helmut Volger, Geschichte der Vereinten Nationen (1995), $16-18$.

129 The Swiss Cantons are granted such capacity by article 56 of the Swiss Federal Constitution (Bundesverfassung der Schweizerischen Eidgenossenschaft, April 18, 1999, 
At first, it would seem plausible to see Hong Kong as an entity similar to such federal subdivisions. Article 31 of the Chinese Constitution provides for the establishment of Special Administrative Regions: Thus, the status of Hong Kong is derived from national constitutional law. Furthermore, the constitutional order of Hong Kong itself has been promulgated by the National People's Congress. Yet the Basic Law enacted by the People's Congress does not merely apply the provision of Article 31 to Hong Kong - it also implements an international treaty, the Joint Declaration, concluded between the United Kingdom and China. ${ }^{130}$ The status of Hong Kong is not only a matter of internal organisation for the Chinese Constitution to determine: Its formulation and observation are ruled by obligations of an international nature. While subdivisions of federal States might well be offered guarantees for their autonomy by the federation, ${ }^{131}$ such guarantees are of a purely municipal nature and may not be invoked on an international level. Thus, Hong Kong lacks the main criterion - exclusive establishment by, and subordination to, a national constitution - of a federal subdivision. And while Hong Kong might share its autonomous status with many federal cantons, states or provinces, the extent of this autonomy exceeds by far the competences usually attributed to federal subdivisions.

History provides a plethora of examples for entities other than States or federal subdivisions carrying some international capacity. They include non-sovereign or dependent territories, de facto territorial regimes, liberation movements, protectorates, trust territories and condominia. ${ }^{132}$ Some of these precedents share certain aspects with the Special Administrative Region of Hong Kong, such as the Free City of Danzig, which was established by the Treaty of Versailles and enjoyed a large degree of autonomy in internal matters, while Poland was responsible for the conduct of its foreign relations. ${ }^{133}$ Danzig was established by, and under the protection of,

art. 56); for the German Länder, see Grundgesetz für die Bundesrepublik Deutschland (federal constitution) art. 23(6), 29(8), and 32(3).

130 Cf. HKSAR vs. Ma Wai Kwan David, [1997] 2 HKC 772 at para. 14.Similar issues were discussed before the Permanent Court of International Justice with regard to the Memel territory: The Statute of the territory was enacted by Lithuania, which consequently claimed it to be part of its national law, rather than of an international convention. The Court dismissed this view, but generally put sovereignty above autonomy (Interpretation of the Statute of the Memel Territory, 1932 P.C.I.J. (ser. A/B) No. 49, at 10, 25-27 (August 11)).

131 See e.g. Swiss Federal Constitution art. 47, for the Swiss cantons.

132 For a detailed discussion see Scheuer, supra note 15, at 161-194.

133 Treaty of Peace, U.K-Fr.-Italy-Japan-U.S.-Germany, art. 104(6), June 28, 1919, 225 CTS 188 [hereinafter Treaty of Versailles]. The status of Danzig is set out in articles 100-108. The international personality of Danzig was recognised by the PCIJ in so far as it was not restricted by treaty obligations creating special relations with the League of Nations and Poland: Free City of Danzig and International Labour Organisation, Advisory Opinion, 1930 P.C.I.J. (ser. B) no. 18; Treatment of Polish Nationals and Other Persons of Polish Origin or Speech in the Danzig Territory, Advisory Opinion, 1932 P.C.I.J. (ser. A/B) no. 44 . 
the League of Nations, which also installed a High Commissioner. ${ }^{134}$ In the case of Hong Kong, however, such a superior authority above the PRC is absent. Also, the treaty setting out the relationship between Danzig and Poland was concluded between the Polish Government and the Free City ${ }^{135}$ while Hong Kong is not a party to the Joint Declaration. The situation of the Territory of Memel, established by a treaty between the European Allied Powers and Lithuania in $1924,{ }^{136}$ was more akin to Hong Kong insofar as the territory - and sovereignty - was transferred to Lithuania. ${ }^{137}$

\section{The Chinese Approach}

For China, the key to its approach to Hong Kong lies in the concept of "one country - two systems". According to this concept, Hong Kong is an inalienable part of the People's Republic that enjoys a high degree of autonomy in so far as it is allowed to maintain a system different from the rest of the country. Hong Kong's status is squarely based on the Basic Law: No mention is made of the Joint Declaration in the NPCSC's interpretations. ${ }^{138}$ It has been pointed out before that in the Chinese conception, the difference in the two systems refers to the economic system only: The mainland would maintain the socialist system, while Hong Kong (and later Taiwan) would be allowed to continue under the capitalist system. ${ }^{139}$ While the PRC has never clearly stated into what kind of international capacity this difference should translate, it probably accepts that Hong Kong does have international personality vis-à-vis third parties, but that its extent is determined, and limited, by the requirements of its practice of capitalism. ${ }^{140}$ In addition, this capacity is perceived as delegated rather than original. Clearly, China considers its own relations with Hong Kong as a purely internal matter with no implications on the international plane; the legal basis for Hong Kong's international status (as for its status as a Special Administrative Region) lies in the Chinese Constitution and the Basic Law as

134 Treaty of Versailles art. 102-103.

135 Treaty of Versailles art. 104.

136 Convention concerning the Territory of Memel, U.K.-Fr.-Italy-Japan-Lith., May 8, 1924, 29 L.N.T.S. 87.

137 "The Memel Territory shall constitute, under the sovereignty of Lithuania, a unit organised on democratic principles, enjoying legislative, judicial, administrative and financial autonomy within the limits prescribed by the present Statute" (Convention concerning the Territory of Memel, Annex I (Statute of the Memel Territory) art. 1). However, disputes over the territory would be of an international character and the Permanent Court of Justice the competent forum (art. 17).

138 Cf. e.g. the most recent Decision of the NPCSC, supra note 85.

139 Deng, supra note 72 , at 14.

140 But see Crawford, supra note 59, at 21, who infers from Chinese statements that for the PRC, Hong Kong has no separate international legal personality of any kind. 
a Chinese law. ${ }^{141}$ Consequently, Hong Kong is an integral part of China which, in some areas and based upon Chinese authorisation, is allowed to make its views known in a limited number of international fora, or to conclude agreements on certain subject matters. It might be considered akin to some form of devolution, the extent of which is delineated by Chinese law. It also means that CEPA is not an international agreement, but merely an accord between a central government and a sub-entity on trade issues, with specific dispute-settlement mechanisms that ought to render recourse to the WTO superfluous. However, while this might rule out a dispute between China and the HKSAR before the WTO in practice, in theory such proceedings between two equal WTO members remain a possibility. In this case, the Chinese view that Hong Kong does not hold any international capacity vis-à-vis the PRC would be difficult to maintain.

\section{Hong Kong's Position}

The Chinese approach is mirrored by the position of the HKSAR executive. It has responded to criticism of Chinese interference by defending the NPCSC's unlimited right - under the Chinese Constitution - to interpret the Basic Law, ${ }^{142}$ and thus set the limits for Hong Kong's international capacity. Tellingly, the Secretary for Constitutional Development became the Secretary for Constitutional Development and Mainland Affairs in July 2007, ${ }^{143}$ underlining that constitutional affairs (which extend to Hong Kong's international status) cannot be separated from relations with the mainland. Hong Kong has played an active role in the latest round of WTO negotiations started in Doha, hosting the Sixth Ministerial Conference in 2005. So the government claims that the implementation of "one country two systems" has brought about new room for development for Hong Kong, and enabled it to participate in numerous international organisations. ${ }^{144}$ Yet the government has never endeavoured to construct its competence to conduct its external affairs in a broad and comprehensive manner: So far, the "new room for development" has not been explored when

141 NPCSC Chairman Wu Bangguo put it particularly bluntly prior to the HKSAR $10^{\text {th }}$ Anniversary: "Our country is a single-system state, and the high degree of autonomy enjoyed by the HKSAR is not intrinsic to Hong Kong but was granted by the Central Government" (NPC warns on HK autonomy, SCMP, June 7, 2007).

142 HKSAR Constitutional and Mainland Affairs Bureau, Response to the US-HK Policy Act Report 2006, Press Release July 5, 2007, available at http://www.cmab.gov.hk/ en/press/press_1563.htm (last visited Apr. 9, 2008).

${ }^{143}$ HKSAR Constitutional and Mainland Affairs Bureau, Welcome Message, available at http://www.cmab.gov.hk/en/about/welcome.htm (last visited Apr. 9, 2008).

${ }^{144}$ HKSAR Government, Government response to false remarks made by Taiwan, Press Release (June 28, 2007), available at http://www.info.gov.hk/gia/general/200706/28/P200 706280344.htm (last visited Apr. 9, 2008). 
compared to the colonial period, and membership in international organisations has not been substantially increased. ${ }^{145}$

Hong Kong citizens themselves certainly do not regard their city as an independent international actor. Partly, this might be due to a genuine sense of belonging: Culturally, most residents of the territory see themselves as Chinese (even though a strict distinction is made between mainlanders and Hong Kongers), and there is a sense of pride in the resurgence of China. At the same time, they find themselves in a familiar situation: A metropolitan power (and a much closer and imminent one, too) has once again the final say on what Hong Kongers, and Hong Kong, might or might not do. Thus, there is a certain sense of despondency when it comes to constitutional matters, and queries on the international status of Hong Kong are dismissed as purely academic: No matter what may be stated by an international treaty, Hong Kong's fate depends on China's benevolence, both on a national and on an international level.

It is doubtful whether the slogan of "one country - two systems" can do justice to the complex situation of Hong Kong. Deng Xiaoping, for one, certainly seemed to have thought so: In his view, the approach of "one country - two systems" even offered "a sensible solution to many similar disputes in the world", in places where "opposing sides are locked in a stalemate". ${ }^{146}$ Numerous such places readily spring to mind: In Kosovo in particular, the international community would have been delighted to find any similar solution prior to a declaration of independence. Yet in most cases where a constitutional framework for diverging interests has to be found, the perceived differences lie in ethnicity, religion, language or culture, rather than in a communist and capitalist economy. This is particularly true in the case of Kosovo. Still, Kosovar statehood might lead to demands for independence elsewhere, and, in turn, to recourse to the "one country - two systems" formula to fend off such demands. The applicability of Deng's concept to other places, however, remains dubious; and even for Hong Kong, it might not be the panacea that he had envisaged. As pointed out above, ${ }^{147}$ the Hong Kong "system" is granted autonomy primarily with regard to the economic field. After fifty years - hence the "expiry date" of the Joint Declaration - the two systems would have approximated and assimilated to a degree that there would only be one country with one system. Indeed, over the past ten years, China has opened up and

145 Hong Kong became a full member of the Western Pacific Regional Forum for the Harmonization of Herbal Medicines (FHH) in 2002. It also joined the Northeast Asia Food Data Systems (2002) and the Association of Film Commissioners International (1999): http://www.info.gov.hk/cab/topical/ (follow "external affairs" hyperlink, last visited Apr. 9, 2008).

146 Deng Xiaoping, A New Approach to Stabilizing the World Situation (Feb. 22, 1984), reprinted in Deng, supra note 71 , at 59 .

147 See supra note 72 and accompanying text. 
liberalised its economy at break-neck speed - narrowing down the gap between the two "systems" and (in China's view) the scope of Hong Kong's autonomy.

Yet clearly, the difference between Hong Kong and the mainland cannot be reduced to their respective economic set-up. As China might discover rather sooner than later, a capitalist system requires many "sub-systems" to ensure its efficient and effective functioning: independent courts, a free press to combat corruption, and general accountability of a community's administrators in periodic elections. There are also signs that the concept "one country - two systems" might be too simplistic to take into account all the "realities" of both China and Hong Kong. As pointed out above, the territory might well qualify as a State in its own right. Consequently, Hong Kong is facing many problems met by States proper, such as constitutional discussions as well as social and environmental issues. Yet with its legal capacity restricted to the economic field, it is frequently not in a position to address these issues in an adequate manner internationally. With the PRC still transforming into an industrialised country and ruled by the Communist Party, it is clear that the mainland and Hong Kong often face different problems requiring different solutions.

\section{IV. “One Country - Two Systems” and the International Community}

The international community acknowledges and tries to accommodate this peculiar situation. Relying on the Joint Declaration, the United Kingdom, the EU and the United States interpret the autonomy granted to Hong Kong in a much broader way. In particular, they refuse to limit it to matters of trade and economy, insisting that it also encompasses the legal and social system, and even certain political rights. ${ }^{148}$ Consequently, they promised to take a factual approach to Hong Kong's international capacity that would rely on this extensive interpretation of its autonomy. In particular, they construe the "two systems" in a more inclusive way and in conformity with the Joint Declaration, which speaks of the social and economic system as well as of Hong Kong's "life-style"149 - which does not refer to fashion or music taste but, as the ensuing list in the Declaration demonstrates, to rights and freedoms, the protection of property, and the legal system. ${ }^{150}$ Yet what measures can the international community - and Britain in particular - take to ensure respect for these guarantees? 
China has entered an international obligation for the way it sets up the HKSAR for half a century. ${ }^{151}$ At the same time, Hong Kong is considered part and parcel of the People's Republic, and China wants to rule it as it sees fit. Is this simply yet another instance of the common problem of domestic implementation of international law, which can generally not be forced upon a State, but which, if not seen through, might entail some form of international responsibility? Or does the fact that the HKSAR was created by an international agreement lead to some stronger form of sanctions on the international level?

The wording of the Joint Declaration is of little help. It does not specify any consequences in case of a breach. ${ }^{152}$ Its registration under Article 102 of the United Nations Charter is a precondition for invoking the Declaration before any organ of the United Nations. It is, however, a necessary condition only, not a sufficient one. For instance, bringing a dispute related to the agreement before the International Court of Justice would presuppose China's consent, as the People's Republic has not accepted compulsory jurisdiction of the Court for the purpose of Article 36(2) of its Statute. Still, the possibility of a referral to the world court was not just discussed by academics, but also by politicians and the public. ${ }^{153}$ The law of treaties would allow for the termination or suspension of a bilateral treaty in case of a material breach by one of the parties. ${ }^{154}$ Yet a repudiation of the Declaration would not restore sovereignty to Britain. ${ }^{155}$ Nor could the United Kingdom invoke a fundamental change of circumstances to withdraw from the treaty: As the Declaration establishes boundaries, this option is barred by Article 62(2)(a) of the Vienna Treaties Convention. Therefore, the law of treaties does not offer effective remedies for a breach of the Declaration.

Still, there might be other, subsidiary remedies open to the United Kingdom should China not honour its obligations. A violation of the Declaration would, as stated above, constitute a breach of an international obligation; furthermore, it would be attributable to the People's Republic under international law, which would thus commit an internationally wrongful act as defined by the International Law Commission in its Draft Articles on State Responsibility. ${ }^{156}$ China would, therefore, be under an obligation

151 See supra note 147 and accompanying text.

152 In other cases, the instruments establishing entities similar to Hong Kong provide for compulsory recourse to an external authority: the Permanent Court of Justice in the case of the Memel territory (Convention concerning the Territory of Memel, supra note 136, art. 17) and the High Commissioner in Danzig (Treaty of Versailles art. 103).

153 Pledge of Honour, SCMP, March 5, 1996.

154 Vienna Treaties Convention art. 60(1).

155 With the Hong Kong Act, 1985, 32 \& 33 Eliz. 2, c.15, Britain had renounced "sovereignty or jurisdiction over any part of Hong Kong” as from 1st July 2007 (\$1(1)).

156 Draft Articles on Responsibility of States for Internationally Wrongful Acts, in In- 
to make full reparation for injuries that its breach of the Declaration might have caused. ${ }^{157}$ Britain would, subject to certain formal and substantive prescriptions, ${ }^{158}$ also be entitled to such countermeasures as set out in Draft Article 49(1). Yet it is difficult to think of any effective countermeasure Britain could (or would want to) take should China decide to ignore the provisions of the Joint Declaration.

\section{British Implementation Measures}

When Prime Minister John Major visited Hong Kong in March 1996, he pledged that Britain "would have the duty to pursue every legal and other avenue available" if the Joint Declaration were breached. If such an event occurred, Britain would also seek international support. ${ }^{159}$ Furthermore, he promised that the United Kingdom would monitor the Human Rights situation in Hong Kong beyond 1997 and raise it in the international arena when necessary. ${ }^{160}$ Yet even though Mr Major stressed that "Hong Kong will never have to walk alone," 161 he remained remarkably vague on what concrete measures Britain would take. To the inhabitants of Hong Kong, his reassurances offered little comfort. The South China Morning Post pointed out that "if Britain cannot convince China of the merits of greater democracy and freedoms for Hong Kong before 1997, there is no reason to believe that it could assume a useful role in this regard after its sovereign link with the territory is severed." In the eyes of Hong Kong people, British authorities were "already a spent force as far as 1997 issues [were] concerned", and the pledge of Mr Major offered "little hope". ${ }^{162}$

Commencing with the handover, the British Foreign and Commonwealth Office has reported in intervals of six months on the implementation of the Joint Declaration. This series of reports is to reflect "the British Government's continuing interest in developments in Hong Kong and [its] commitment to the faithful implementation of the Sino-British Joint

ternational Law Commission, Report on the work of its 53rd session (Apr. 23 - June 1 and Jul. 2 - August 10, 2001), UN Doc. A/56/10 [hereinafter Draft Articles on State Responsibility], 43. Even though the articles have not yet been adopted, they are accepted as evidence of general international law relating to State responsibility.

157 Draft Articles on State Responsibility art. 31(1).

158 Draft Articles on State Responsibility art. 49(2), 50-52.

159 Pledge of Honour, SCMP, Mar. 5, 1996.

160 A. Ho, Royal Wrangle Generates More Interest Than Major's Rhetoric, SCMP, Mar. $5,1996$.

161 C. Yeung, Major Pledges Push on Visa-free Access, SCMP, Mar. 5, 1996.

162 A. Ho, supra note 160. In 1997, economic sanctions were also discussed as an option (Lim Wan-Yee, Analyst Warns of Sanctions Catch 22 if Treaty Ignored, SCMP, Jul. 12, 1997). That such a suggestion could still be made in 1997 indicates how rapidly Chinese economic power has risen over the past few years. 
Declaration." 163 The reports monitor constitutional development, the protection of basic rights and freedoms, economic developments, bilateral and international relations as well as the implementation of the principle "one country - two systems". China is not taken with this approach: The release of the 2003 report (July-December) has been condemned by the spokesperson of the Chinese Foreign Ministry as an "interference in China's internal affairs". It was, the spokesperson maintained, "inappropriate for the British side to issue a so-called Hong Kong Report to make improper comments on Hong Kong affairs." 164 It is difficult to fathom the motivation for this statement, unless it is a result of the Chinese reflex to jealously guard its sovereignty. The international and binding nature of the Declaration has, if grudgingly, been accepted by China. Naturally, Britain is entitled to report on the implementation of an international agreement to which it is a party.

In the January-June 2004 Report, the Foreign and Commonwealth Office (FCO) expressed its concerns over the decision of the NPCSC to rule out universal suffrage beyond 2007/08. ${ }^{165}$ As then-Foreign Secretary Jack Straw pointed out, "these moves seem to erode the high degree of autonomy promised to Hong Kong in the Joint Declaration.”166 The Report also set out the weak legal argument on which the NPCSC based its decision, and suggested that if the issue could not be resolved on a political level, it should be referred to the courts of Hong Kong. Independent interpretation of the law was an important part of Hong Kong's common law system guaranteed in the Joint Declaration, and further interpretation by the NPCSC would undermine Hong Kong's separate legal system as well as confidence in the rule of law. ${ }^{167}$ However, these observations only resulted in a joint statement by Prime Minister Tony Blair and his Chinese counterpart Wen Jiabao which, after a "friendly and open exchange of views on issues relating to Hong Kong”, reaffirmed the "two Governments' commitment to the implementation of the Joint Declaration". 168

The latest FCO Report repeats that the legal status of Hong Kong is based on the Joint Declaration rather than the Basic Law, but concludes

163 Secretary of State for Foreign and Commonwealth Affairs, Six-monthly Report on Hong Kong, July-December 2003 (Cm 6125, 2004), para. 1.

164 The Spokesperson's Remarks on the "Half Year Report on Hong Kong” Issued by the British Foreign and Commonwealth Office (Feb. 24, 2004), http://www.fmprc.gov.cn/ eng/xwfw/2510/2535/t67905.htm (last visited Apr. 9, 2008).

${ }^{165} \mathrm{Cf}$. Decision of the Standing Committee of the NPC on issues relating to the Methods for selecting the Chief Executive of the HKSAR in the Year 2007 and for forming the Legislative Council of the HKSAR in the Year 2008, April 26, 2004, available at http://www. info.gov.hk/basic_law/fulltext/0426npcsc_e.pdf (last visited Apr. 9, 2008).

166 Secretary of State for Foreign and Commonwealth Affairs, Six-monthly Report on Hong Kong, January-June 2004 (Cm 6292, 2004), at iii.

167 Id. para. 28.

168 Id. para. 51. 
that "one country - two systems" has generally worked well and that the freedoms promised in the Joint Declaration continue to be upheld. ${ }^{169}$

\section{International Measures and Remedies?}

Yet Britain is not the only country reporting on the situation in Hong Kong. As early as 1992, Congress enacted the United States - Hong Kong Policy Act, ${ }^{170}$ stating that its "strong economic, cultural, and other ties" with Hong Kong gave the United States "a strong interest in the continued vitality, prosperity, and stability of Hong Kong”. ${ }^{171}$ Congress recognised that under the Sino-British Joint Declaration, sovereignty over Hong Kong would revert to China in 1997, but emphasised that the city should enjoy a high degree of autonomy and retain its current legal, political and economic framework "until at least 2047". ${ }^{172}$ Congress also expressed "its wish to see full implementation of the provisions of the Joint Declaration", ${ }^{173}$ and reaffirmed its intention to "actively seek to establish and expand direct bilateral ties and agreements with Hong Kong in economic, trade, financial, monetary, aviation, shipping, communications, tourism, cultural, sport, and other appropriate areas." 174 The Hong Kong Policy Act also provides for the maintenance of the United States Consulate General in Hong Kong, and in turn encourages Hong Kong to maintain its official and semi-official missions in the United States beyond 1997. ${ }^{175}$ Furthermore, the United States would not treat Hong Kong residents as Chinese nationals for the purpose of temporary or permanent visas. ${ }^{176}$ The United States also declared that it intended to support Hong Kong's participation in "all appropriate multilateral conferences, agreements, and organizations in which Hong Kong is eligible to participate." 177 In addition, the Secretary of State is requested to submit, up to the year 2000, regular reports on Hong Kong to both houses. ${ }^{178}$

In general, American support for the implementation of the Joint Declaration - as interpreted by the United States - has been continuous, strong,

169 Secretary of State for Foreign and Commonwealth Affairs, Six-monthly Report on Hong Kong, January-June 2007 (Cm 7180, 2007), paras. 38, 87, 106.

170 United States - Hong Kong Policy Act of 1992, Public Law 102-383, 102nd Cong. (1992).

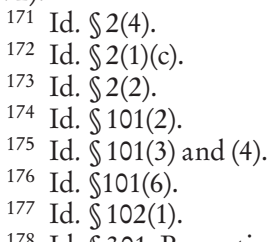

178 Id. $\$ 301$. Reporting has continued on an annual basis after 2000 , cf. the latest report: U.S. Department of State, U.S.-Hong Kong Policy Act Report (June 30, 2007), http://www. state.gov/p/eap/rls/rpt/65340.htm (last visited Apr. 9, 2008). 
and assertive. In 2003, both houses of Congress have passed resolutions condemning any steps leading to a restriction of fundamental freedoms in Hong Kong. ${ }^{179}$ Unsurprisingly, the resolutions have evoked harsh Chinese reactions, urging the United States "to refrain from words or deeds which constitute an interference in China's and Hong Kong SAR's internal affairs" and which "could harm Sino-US relations". ${ }^{180}$ To the displeasure of the PRC, the United States also regularly receives pro-democracy politicians from Hong Kong. ${ }^{181}$

The American policy is mirrored by the approach of the European Union. At the Dublin Summit in 1996, the European Council proclaimed "the European Union's strong interest in the future peace and prosperity" of Hong Kong, and underlined its "continuing support for and commitment to the principle that all the rights granted to Hong Kong Citizens ... should be fully respected". ${ }^{182}$ The Union would aim to "deal directly with Hong Kong" in "areas within the responsibility of the SAR Government"183 and beyond the economic realm. ${ }^{184}$ The EU also made it clear that the only authoritative source for delineating the extent of these responsibilities is the Joint Declaration, ${ }^{185}$ and not Chinese legislation such as the Basic Law. Once more, the nature of the Joint Declaration as a binding treaty is stressed: "Deposited as an international agreement at the United Nations", it would "continue to regulate Hong Kong until 1 July 2047". ${ }^{186}$ Furthermore, the EU established an office in Hong Kong to liaise directly with the SAR Government, an approach also to be pursued by the EU in international organisations to which Hong Kong is a separate party. ${ }^{187}$ With a view to Hong Kong's legal personality, the Commission stressed the importance of maintaining the territory's international role and its separate membership in international organisations as well as its capacity to sign

179 H. Res. 277, 108th Cong. (2003), S. J. Res. 14, 108th Cong. (2003).

180 Spokesperson on US Resolution on the Issue of Legislation according to Article 23 of the Basic Law of Hong Kong (1 July 2003), http://www.fmprc.gov.cn/eng/xwfw/2510/2535/ t22771.htm (last visited Apr. 9, 2008); Foreign Ministry Spokesman's Remarks on the US State Department Spokesman's Comment on the Development of Hong Kong's Political System (10 January 2004), http://www.fmprc.gov.cn/eng/xwfw/2510/2535/t58285.htm (last visited Apr. 9, 2008).

181 Democrats to Report to US Senate Committee, SCMP, Mar. 2, 2004.

182 European Commission, The European Union and Hong Kong: Beyond 1997, $\operatorname{COM}(97) 171$ final (23 Apr 1997), paras. 1, 12.

183 European Commission, supra note 182, para. 12. The words "deal directly with Hong Kong" are emphasised in the original.

184 "The SAR concept is not limited to trade and economic matters. Its provisions cementing an independent administration, a distinct legal system guaranteeing the rule of law, a separate elected legislature, a free Press, and a series of fundamental rights and privileges are all core elements in the package" (European Commission, supra note 182, para. 12.

185 European Commission, supra note 182, para. 12.

186 European Commission, supra note 182, para. 3.

187 European Commission, supra note 182, para. 12. 
international agreements in the area under its responsibility. ${ }^{188}$ As an additional means to recognise Hong Kong's autonomy, the EU would assess it separately for the purposes of the common visa list of the Union. ${ }^{189}$ Since 1999, the Commission also issues annual reports on Hong Kong. ${ }^{190}$ In 2006, the European Commission proposed the establishment of annual meetings on matters within the competence of the HKSAR government in order to strengthen direct bilateral links. ${ }^{191}$ The first edition of this "Structured Dialogue" between Hong Kong and the EU was held in November 2007 in Hong Kong. ${ }^{192}$

While such initiatives and regular reporting may have some political impact, their legal relevance remains doubtful. Contrary to Britain, which, as a signatory of the Joint Declaration, has rights and duties under it, neither the United States nor the European Union are parties to this bilateral agreement. The Joint Declaration does not accord rights to third States, nor does it create any erga omnes obligation of China. The PRC, which has initially rejected any international agreement on Hong Kong, would hardly accept the view that the Declaration entitled the international community to play a role "in ensuring that the SAR lives up to its task and the responsibilities it has been given under the Joint Declaration". ${ }^{193}$

Yet the main reason why such outside efforts will, eventually, have little impact on Hong Kong's international standing, is not based on international treaty law. Reporting by the EU or the United States cannot, by itself, lead to a more internationally active and assertive Hong Kong. Such measures may support and encourage the HKSAR executive in fulfilling ambitions of an international nature, yet it cannot create such ambitions. First and foremost, it would be up to the HKSAR to make full use of the international capacity of sorts that the Declaration has granted, and to try and ensure its international interests when and insofar as they differ from the interest of the PRC (and it has been shown that there are significant differences on a number of issues). The HKSAR executive, however, seems to harbour few if any ambitions on the international plane. It may have hosted the WTO summit, but this seems to have originated in public relations concerns related to SARS rather than an assertive stance on Special Ad-

188 European Commission, supra note 182, para. 7.

189 Id. Currently, Hong Kong residents do not require a visa to enter the European Union for less than three months: Council Regulation 539/2001, Annex II, 2001 O.J. (L 81) 7 (EC).

190 All reports are available at http://ec.europa.eu/external_relations/hong_kong/doc/ index.htm (last visited Apr. 9, 2008). The latest report states "that in general the "one country - two systems' principle has been respected and is working well for the people of Hong Kong” (European Commission, Hong Kong Special Administrative Region: Annual Report 2007, COM (2008) 118 final (March 3, 2008), 7).

191 European Commission, The European Union, Hong Kong and Macao: Possibilities for Cooperation 2007-2013, COM (2006) 648 final (26 Oct. 2006), 10-11.

192 Cf. European Commission, supra note 190, at 5.

193 European Commission, supra note 182, para. 12. 
ministrative Region's role in trade negotiations. Instead of testing the boundaries of "external affairs", Hong Kong has been most forthcoming in echoing Chinese condemnation of "foreign meddling in Chinese internal affairs". ${ }^{194}$ True, during a speech at a luncheon hosted in honour of Jose Manuel Barroso, the President of the European Commission, Chief Executive Donald Tsang stated optimistically that Hong Kong was now "poised for even bigger and better things". ${ }^{195}$ But as the first two examples, he informed his guest that Disneyland Hong Kong would soon open, and that the equestrian events of the Olympic Games 2008 would take place in Hong Kong - hardly the international status and stature that the Joint Declaration had envisaged in 1984.

\section{Conclusion}

Hong Kong raises a number of issues under international law. Firstly, its legal status is difficult to pinpoint. Even though it looks like a State and frequently acts like one, there can be no doubt that it does not qualify as a State because it has never claimed statehood, and sovereignty rests with China. Apart from ruling out statehood, however, it is difficult to make any conclusive statements on the nature of its legal capacity. A federal entity it is not, nor an administrative subdivision. Perhaps it should best be described as an entity sui generis (which does not help much to illuminate its position on the international level).

Secondly, there can be no doubt that, according to the Joint Declaration, Hong Kong should be able to assume an independent legal capacity with regard to international economic and cultural relations. Hong Kong has continued independent membership in several international organisations, most notably the WTO and APEC. Yet there are several other organisations of which Hong Kong is not a member, even though it would benefit greatly from independent participation. This applies, first and foremost, to the Specialised Agencies of the United Nations that offer associate membership.

Even though this paper focussed on Hong Kong's international legal status, the "domestic" aspect of the Joint Declaration still matters for that purpose. If international status is not supported by some substantial autonomy on the domestic level, it will amount to little more than formal

194 HKSAR Government, HKSAR Government responds to US Congress House of Representatives' Resolution, Press Release (Sept. 14, 2004), http://www.info.gov.hk/gia/ general/200409/14/0914256.htm (last visited Apr. 9, 2008).

${ }_{195}$ HKSAR Government, CE speaks at luncheon in honour of President of European Commission, Press Release (18 July 2005), http://www.info.gov.hk/gia/general/200507/18/ 07180166.htm (last visited Apr. 9, 2008). 
posturing on behalf of the true sovereign, as "independent" UN membership of Byelorussia and Ukraine in the Soviet era illustrates. Whether China adheres to the commitment of granting Hong Kong autonomy - internally and, to a limited extent, externally - will therefore be decided by the degree of its interference in governing the SAR. Deng Xiaoping had set out the principle of "Hong Kong people ruling Hong Kong", but his successors have shown an increasing willingness to interfere in matters that, under the Joint Declaration, should fall under Hong Kong's "high degree of autonomy". With every ruling of the NPCSC on quintessentially domestic matters of the HKSAR, this autonomy is further undermined, as is the rule of the common law and its tradition of judicial review. This development has tarnished the attractiveness of the "one country - two systems" principle (and Taiwan has noticed). ${ }^{196}$

The Declaration is not out of joint yet. Hong Kong does indeed enjoy considerable autonomy, and limited capacity on the international level. Yet the continuous twisting by the Central Government has certainly led to some strain, and might eventually result in dislocation, which is, however, likely to occur gradually rather than with a bang. Responsibility to prevent such an outcome would, primarily, fall on the other party to the Declaration, the United Kingdom. Yet Britain is not in a position to impose its views on China - not least because 150 years of colonial rule without devolution make it difficult to claim the moral high ground. Thus, the extent of Hong Kong's autonomy might eventually be determined by how far Hong Kong itself is willing to explore the possibilities opened up by the Declaration. Clearly, the Central Government will keep a watchful eye on any such venture; but it has to be kept in mind that on most occasions, it was the Executive of the Special Administrative Region that has had recourse to mainland authorities whenever it felt overtaxed by demands of its own citizenry. The colonial spirit is still lingering; sometimes, the executive seems to act as a mere deputy for (anticipated) mainland policies, rather than pursuing its own agenda. Yet the interests of the mainland and the Special Administrative Region are not necessarily congruent. China certainly supports stability and prosperity in Hong Kong, but at the same time it might prefer to support the economic development of mainland cities, notably Shanghai, rather than propping up a former British outpost.

196 Mainland Affairs Council (Republic of China), Analysis Report: 10 Years after Hong Kong's Handover (June 28, 2007), available at http://www.mac.gov.tw/english/english/ macpolicy/hk10e.pdf (last visited Apr. 9, 2008); Mainland Affairs Council (Republic of China), China's Violation of Its Promises Regarding the Implementation of the "One Country, Two Systems” Formula in Hong Kong (June 28, 2007), available at http://www.mac.gov. tw/english/english/macpolicy/violation.pdf (last visited Apr. 9, 2008). 


\section{Summary}

On July 1, 2007, the Hong Kong Special Administrative Region (HKSAR) celebrated its tenth anniversary. While constitutional reform (or its absence) in the former colony are still closely followed, the international legal aspects of the "one country - two systems" approach adopted for Hong Kong have generally received little attention since the handover.

It is argued here that under the Sino-British Joint Declaration of 1984, the HKSAR has been granted limited international legal capacity: It may maintain and develop relations with States and relevant international organizations, and conclude agreements in the appropriate fields.

The nature of Hong Kong's international personality is difficult to establish, with no apparent equivalent except Macao. The present extent of its legal capacity would seem similar to British rule, when the colony was already largely responsible for the conduct of international economic relations. Yet even more so than in colonial times, such a limited approach seems inappropriate for an entity that would, on almost all accounts, qualify as a State. The new sovereign tends to construe the "appropriate fields" for international capacity in a narrow sense and, arguably, in a narrower sense than envisaged by the Joint Declaration. However, it would be the responsibility of Hong Kong's executive to explore the international options that the Declaration offers. 